\title{
Four Streams of Democracy and the Recognition of States: the EU Perspective
}

\author{
Sava JANKOVIC*
}

\begin{abstract}
This article argues that there exist four streams of democracy which underpin the recognition policy of the EU and its Member States. Recourse to the democratic idea is manifested when the EU and its Member States acknowledge either a) that the claimant people have a legal right to external self-determination; or b) that the people deserve statehood for moral grounds; or c) that the people concerned have reached a consensus with the Mother State regarding secession; or $\mathrm{d}$ ) that the government has been committed to certain democratic values and standards (democracy par excellence). Recognition in the first three scenarios (streams) legitimizes people's desire to self-rule (demos kratos) while in the fourth comes as an act which validates a specific form of rule i.e. democratic governance. The article will in particular seek to determine whether the famous 1991 EC Guidelines on the Recognition of New States in Eastern Europe and in the Soviet Union, which made recognition conditional upon the adoption of liberal democracy standards remain valid today
\end{abstract}

Keywords: Recognition of States - Democracy - Self-Determination - European Union

\section{(A) CONTEMPORARY CRITERIA FOR RECOGNITION OF NEW STATES}

The most apparent present-day tendency, both in the academic milieu and in official public announcements regarding the recognition of States revolves around the notion of whether an entity is a State in terms of international law. Put differently, whether it fulfils statehood criteria set by this law. State practice evinces indeed that due regard is paid to Article I of the Montevideo Convention, which provides that a State should dispose of the following qualifications: a) a permanent population; b) a defined territory; c) government; and d) capacity to enter into relations with other State. ${ }^{\mathrm{I}}$ For example, in 1948, the Netherlands' government was unwilling to go ahead with the recognition of the State of Israel on the grounds that borders of that country had not been adequately established. ${ }^{2}$ In contrast, the US, France and the Soviet Union, also alluding to Montevideo criteria, arrived at different conclusions (in their opinion the requirement of defined borders should be interpreted more flexibly) and did

* Doctor of International Law. This paper was presented at the workshop on democratic governance organized by the Manchester International Law Centre on the $3 \mathrm{rd}$ of November 2017. The aim of the workshop was to revisit the state of the practice in international law twenty-five years after this narrative attracted attention in international legal scholarship following the publication of Tom Franck's seminal article The Emerging Right to Democratic Governance in 1992 in the American Journal of International Law.

I Montevideo Convention on the Rights and Duties of States (adopted 26 December 1933, entered into force 26 December 1934) 165 LNTS 19 (hereinafter cited as the Montevideo Convention) Art. I.

2 Memorandum of reply, Bijl A Hand. II 1948/1949-1000 III No. I2 at 20. 
recognize Israel.3 Singapore's representative in the UN General Assembly during the voting on Resolution 67/19, which concerned upgrading of Palestine's status in the UN to 'non-member observer state', declared that his opposition to the text was premised on the factual (Montevideo) criteria, which Palestine had not satisfied. ${ }^{4}$ The majority of commentators and statespersons are in accord that the concept of State evolved from the minimalistic quaternary enumeration enshrined in Article I of the Montevideo Convention and the decision on recognition should encapsulate the development of law in that regard considering, in particular, the right to self-determination and the prohibition of the use of force. 5 In other words, an entity should be recognized as a State if it came into existence in harmony with international law, and a contrario, recognition should be withheld if it emerged in violation of peremptory norms of international law. ${ }^{6}$ State practice seems to corroborate that. With regard to resort to the threat or use of force, the annexation of the Golan Heights in 198I by Israel, the annexation of Kuwait by Iraq in 1991 or the 'incorporation' of Crimea into Russia in 2014 might be invoked, all of which, of course, were roundly condemned by the international community.7 In respect to the breach of self-determination right, memories bring back a year 1965 and the Rhodesian white regime, which neglecting the will of domestic Zimbabweans, decided upon the creation of a State known as Southern Rhodesia. A comparable situation occurred with South African Bantustans (Transkei, Bophuthatswana, Venda, and Ciskei) which existed between 1976-1981 to secure the preference of life of the white people through the creation of homelands for black tribes'. The UN's vociferous critique and call for non-recognition are reflected in plentiful resolutions. ${ }^{8}$

Apart from espousing de lege lata arguments regarding the conception of a State in international law, States while deciding on recognition not infrequently rely on appurtenant facets, which constitute rather de lega ferenda. In the former situation, criteria for recognition are conflated with criteria for statehood, while not in the latter, which describe the subjective, idealistic or preferred vision of statehood, propounding what a State should look like. For

3 H. Panhuys, International Law in the Netherlands vol I (Sijthoff \& Noordhoff, The Hague, 1978), at 374.

4 UN Doc. A/67/PV.44, at I4. See also statements made by the US, at I3 and the UK, at I5 (UK).

5 A. Peters, 'Statehood after 1989: "Effectivités" between Legality and Virtuality' in J. Crawford and S. Nouwen (eds), Select Proceedings of the European Society of International Law (Hart Publishing, Portland, 20I2), at I7I-I84.

6 See Art. 4I(2) of the Articles of the International Law Commission (ILC) on the Responsibility of States for Internationally Wrongful Acts, GA Res. 56/83, I2 December $200 I$.

7 See respectively SC Res. 479, 28 September 1980 and SC Res. 662, 9 August 1990; GA Res. 68/262, 27 March 2014.

8 SC Res. 216, I2 November 1965; SC Res 217, 20 November 1965; SC Res. 402, 22 December 1976; SC Res. 407, 25 May 1977 and SC Res. 283, 29 July 1970; J. Dugard, 'Collective non-recognition: The failure of South Africa's Bantustan states' in B. Ghali (ed), Amicorum Discipulorumque Liber vol I (Bruylant, Bruxelles, 1998), at $383-403$. 
instance, the criterion of the ability and willingness to observe international law and discharge international responsibility may be a condition for recognition, whereas it is not a condition for statehood (perhaps with a more lax approach to Article 4(I) of the UN Charter, stipulating the necessity of carrying out obligations contained in the Charter). ${ }^{9}$ Norway in her Royal Decree of 28 March 2008, the purpose of which was to recognize Kosovo as an independent State and explain the basis of Norwegian recognition, underlined that she decided to afford recognition on the strength of assurances contained in the Declaration of Independence promulgated by the Assembly of Kosovo on the $17^{\text {th }}$ of February 2008, which she considers binding under international law. In the Decree, Norway underscored the commitment of Kosovo's authorities to guarantee community rights, provide protection of the Serbian Orthodox Church and show respect for international law norms.

The next in turn criterion for recognition, embedded chiefly in the German conception of statehood, is the evidence of legal order, most notably a constitution. Dellbrück and Wolfrum in their classic work about subjects of international law (die Völkerrechtssubjekte) suggest that to a State belongs also - whether written or not - a constitution, whose aim is to regulate a relationship between the government and other organs to which certain functions and competencies are allocated. ${ }^{\text {Io }}$ Again, it is rather evident that the constitution is a sheer criterion for recognition and not statehood. There exist non-state actors, alike dependent States that possess it (e.g. the constitution of the Falkland Islands) yet not being regarded as sovereign States. Similarly, States may adopt it afterwards (Belarus adopted its constitution three years after the declaration of independence in 199I). The possession of constitution per se is a hardly articulated argument for recognition, although some States give weight to it. The Czech statement remarks that 'the Assembly of Kosovo passed a constitution [...] a Foreign Ministry, as well as a Ministry for Security Forces, was established [...]. Despite these developments, there are still many States that have not yet recognized Kosovo'." Germany in her statement mentions that on the 15th of June Kosovo's constitution entered into force and that it contains a comprehensive set of laws, establishing new institutions, intelligence agency and diplomatic service, and regulating citizenship and promotion of the rights of communities..$^{12}$

Further implications, which may be deemed as eliciting recognition of States centre on permanence and economic viability. The American Law Institute's Drafts Restatement $\left(2^{\mathrm{nd}}\right)$ mentions permanence as a precondition for recognition of statehood. ${ }^{13}$ Happold in his report

\footnotetext{
9 See C. Hillgruber, 'The Admission of New States to the International Community' 9 EJIL (1998) 49I, at 499.

Io G. Dahm, J. Delbrück and R. Wolfrum, Völkerrecht, vol I (De Gruyter, Berlin, 1989), at I28.

II Written statement of the Czech Republic (I4 April 2009), at 4.

I2 Written statement of Germany (I5 April 2009), at 25.

13 Restatement $\left[2^{\text {nd }}\right]$ Foreign Relations Law of the United States (1965), s. 100.
} 
prepared for the ILA Conference in Sofia in 2012 suggests that the UK shares the American point of view.14 The criteria which the UK Government purports to apply for the recognition of States were set out in a Written Answer dated 16 November 1989 by the then Parliamentary Under-Secretary of State for Foreign and Commonwealth Affairs. ${ }^{\text {I5 }}$ In pursuance of it, States 'should have, and seem likely to continue to bave, a clearly defined territory with a population, a government who are themselves able to exercise effective control of that territory, and independence in their external relations. ${ }^{16}$ Permanence seems to be a preventive measure for admittance into the community of States new States, which may temporarily fulfil statehood trappings and soon become failed States.

Having enumerated some of the 'official' criteria for recognition of States, which either permeate legal thought of international legal scholarship or are invoked by States' representatives, it is worth observing that this list is by no means exhaustive. Save for the criterion of democracy, which I decided to single out due to its pivotal importance for the present essay, there may exist further criteria.

(B) DEMOCRACY AS A CRITERION FOR RECOGNITION OF STATES: PRACTICAL AND THEORETICAL CONSIDERATIONS OF THE FOUR-STREAM APPROACH

There are four streams underlying the rationale behind invoking democracy in recognition of States: legal, moral, consensual and par excellence. They not infrequently overlap and it is difficult to categorically affirm the prevalence of one or another as distilled from the State practice.

The first one predicates on the correlation between democracy and the right to selfdetermination. At its roots lie the American (1776) and French Revolution (1789) which underscored the endogenous endeavours of human beings to emancipate from domination and to decide on their fate. In the course of time, the right to self-determination evolved from the philosophical conception to a legal right..$^{17}$ Nowadays, it is treated as a universal, erga omnes right, classified among jus cogens norms..$^{18}$ Its assumptions directly evoke the original Greek

I4 Committee on Recognition/Non-recognition in International Law, 'First report on Recognition/Nonrecognition in Contemporary International Law' in International Law Association Report of the Seventy-Fifth Conference (Sofia 20I2) (International Law Association, Sofia 2012) 164, at I70-I7I.

is Hansard HofC Session 1988-89, column 494.

16 Ibid.

${ }_{17}$ A. Cassese, Self-Determination of Peoples: A Legal Reappraisal (CUP, Cambridge, 1995), at 37-66.

I8 See UNHCR (Sub-Commission), 'Study by Special Rapporteur Hector Gros Espiell' (1980) UN Doc. E/CN.4/Sub.2/405/Rev.I, at II-I3. For a list of jus cogens norms defined by the International Law Commission see ILC, 'Report of the International Law Commission on the Work of its 53rd Session' (23 April-I June and 2 July-Io August 200I) UN Doc. A/56/Io, at 283-284, paras. 4,5. 
meaning of self-governance of people (demos - people, kratos - rule) providing that in virtue of self-determination people can 'determine their political status and freely pursue their economic, social and cultural development'. ${ }^{19}$

The legal right of self-determination has been only accepted in part by States. States are in accord to extend recognition to people who were previously colonized and perpetuate recognition to those whose territories were occupied after 1945 (Kuwait) - in view of the prohibition of the use of force. Legal contours for statehood and recognition were provided in the UN Declaration on the Granting of Independence to Colonial Countries and Peoples, ${ }^{20}$ and principle VI of the UNGA Resolution 1541, pursuant to which a Non-Self-Governing Territory can be said to have reached a full measure of self-government by either a) emergence as a sovereign independent State, or b) free association with an independent State or c) integration with an independent State. ${ }^{2 I}$ The ICJ jurisprudence reaffirmed this right in the Namibia, Western Sabara, Wall and East Timor cases. ${ }^{22}$ The legal right to self-determination of colonized people is unequivocal and meets, in principle, with universal recognition. The fact the UN original membership amounted to 5I States in 1945 and there are 193 Members States now, corroborates this. ${ }^{23}$ Nevertheless, the realization of the right itself, and ensuing recognition, may sometimes take a long time (East Timor was admitted to the UN in 2002, the ICJ ruling occurred in 1995), depend on the outcome of a referendum (yet to be conducted in Western Sahara, the ICJ ruling was in 1975) or hinge on a bilateral agreement (the case of Palestine which would demand mutual recognition with Israel).24 There are still 17 territories which await the realization of self-determination, and possible recognition (if they choose to declare independence). A hope exists that their status may be definitely resolved during the Fourth International Decade for the Eradication of Colonialism (202I-2030).25

19 International Covenant on Civil and Political Rights (adopted 16 December 1966, entered into force 23 March 1976) 999 UNTS I7I (hereinafter cited as ICCPR) Art. I.; International Covenant on Economic, Social and Cultural Rights (adopted 16 December 1966, entered into force 3 January 1976) 993 UNTS 3 (hereinafter cited as ICESCR) Art. I. See also The UN Charter, Art. I(2).

20 GA Res. 1514 (XV), I4 December 1960.

21 GA Res. 154I (XV), is December 1960.

22 Legal Consequences for States of the Continued Presence of South Africa in Namibia (South West Africa) notwithstanding Security Council Resolution 276 (1970), ICJ Reports (1971) 16, paras. 52-53; Western Sahara, ICJ Reports (1975) I2, paras. 54-59; East Timor (Portugal v. Australia), ICJ Reports (1995) 95, paras 29, 33, 37; Legal Consequences of the Construction of a Wall in the Occupied Palestinian Territory, ICJ Reports (2004) I36, paras I22, I49, 155 .

23 Available here, accessed Io October 2018.

24 See, inter alia, Israeli-Palestinian Interim Agreement on the West Bank and the Gaza Strip (Oslo II) (28 September 1995) 36 ILM (1997), at 551. As for now, Palestine has been recognized by 136 UN Members and Western Sahara by 84 (of which 37 have frozen or withdrawn recognition).

${ }^{25}$ L. Antonowicz, 'Czy zakończenie dekolonizacji zostało odroczone ad infinitum?' in B. Krzan (ed), Ubi ius, ibi remedium: księga dedykowana pamięci profesora Jana Kolasy (CH Beck, Warsaw, 2016), at I-9. 
In spite of concordance amongst States in the context of decolonization and illegal occupation, the legal right of people to self-determination in other cases is not always tantamount to statehood. Put differently, not all people have the right to create a State. This is so because States were unable to agree which other subjects could benefit from the right (who is 'the people'). ${ }^{26}$ From the reading of the Badinter Commission Opinion No. 2, it seems that national minorities are not entitled to this right. The Commission stated that Serbs in Croatia (Republika Srpska Krajina) and Bosnia (Republika Srpska) cannot instigate independent States. ${ }^{27}$ Besides, as evidenced by the continuous practice of States, it appears very unlikely that such a category will ever be defined and accepted in view of its apparent collision with the principle of territorial integrity, to which States are highly committed. Against this backdrop, the right to self-determination, although remains important, is generally considered to be realized within an existing State. ${ }^{28}$ For these reasons neither Chechens, Kurds, Tibetans, Quebecers nor Eelam Tamils have been able to secure international recognition. It is worth adding that the right to self-determination will not lead to a recognized statehood if accomplished with the aid of foreign military assistance (Northern Cyprus, Abkhazia, South Ossetia and Crimea).29

Recapitulating the relationship between the recognition of States and democracy within the legal stream, a conclusion must be that they are not entirely complementary. The legitimacy is clearly evident in States' behaviour towards the entities whom they granted the unequivocal right to self-determination, including the right to create a new State. Additionally, the adherence to commitments of permanent recognition of people's right under effective occupation is compatible with the basic principle of democracy. However, the strict reading of law protecting existing borders of States together with non-acceptance of military assistance to the majority of people longing for statehood may be at odds with the fundamental understanding of democracy.

${ }_{26}$ J. Summers, Peoples and International Law: How Nationalism and Self-Determination Shape Law of Nations (Martinus Nijhoff, Leiden, 2007), at I-2.

27 A. Pellet, "The Opinions of the Badinter Arbitration Committee A Second Breath for the SelfDetermination of Peoples' 3 EJIL (1992) I78, at I83-184. See also opinion of Stefan Talmon regarding Catalonians here, accessed Io October 2018.

${ }_{28}$ J. Vidmar, 'Territorial Entitlement and Exit Scenarios' in M. Nicolini, F. Palermo and E. Milano (eds), Law, Territory and Conflict Resolution (Brill, Leiden, 2016) I05, at II2-II3.

29 Peters, supra n. 5. See also, Declaration of Principles of International Law Concerning Friendly Relations and Co-operation Among States in Accordance With the Charter of the United Nations (No territorial acquisition resulting from the threat or use of force shall be recognized as legal), GA Res. 2625, 24 October 1970. On the issue of the majority of population favouring secession refer to international reports. For Crimea see here, accessed Io October 20I8. Cf. A Peters, Sense and Nonsense of Territorial Referendums in Ukraine, and Why the 16 March Referendum in Crimea Does Not Justify Crimea's Alteration of Territorial Status under International Law (2014) EIJL: Talk!, accessed ro October 2018. 
The second motive for the recognition of States rests on moral foundations, which do not have support in law. According to this version, people who are either substantially and continuously deprived of the capacity to decide on their own fate within the existing State (they cannot realize the internal right to self-determination) or are subject to subjugation and exploitation or their human rights are violated in another way, are entitled to separation..$^{\circ}$ Judge Antônio Augusto Cançado Trindade emphatically argued in his separate opinion in the Kosovo Advisory Opinion case that 'No State can use territory to destroy the population. Such atrocities amount to an absurd reversal of the ends of the State, which was created and exists for human beings, and not vice-versa' ${ }^{31}$ Scholars and States advocating the right to separate in extreme circumstances, where no other solution can be found, refer to it as 'ultima ratio secession' or 'remedial secession'.$^{2}$ It goes without saying that at the core of the so-called remedial secession lies the concept of legitimacy. Main problems of this approach are the lack of sufficient practice, broad dissonance among States in terms of its acceptance and the possibility of politicization. Therefore, the recourse to remedial secession carries a risk that an entity in question will remain non-universally recognized. In the Kosovo Advisory Opinion, the US, the UK, Albania, Germany, Poland, Switzerland, Estonia, Ireland and Latvia invoked the right to remedial secession. On the other hand, the right was opposed by Serbia, Russia, Iran, Spain, Argentina, Bolivia, Azerbaijan, Romania, Libya and Venezuela.33 The lack of practice is determined by the fact that this approach is not substantiated by any positive law, the possibilities to exert it are limited (the much academically praised humanitarian intervention was rejected by 133 States at the South Summit of the Group of 77$)^{34}$ and that it is difficult to define the threshold which would corroborate the secession.

The third stream, which is here termed as consensual, represents the most convenient apprehension of facts by existing States. States are usually content with the compromise reached between parties and extend their recognition. An a priori assumption of grassroots democracy is inherent in States' decision on recognition and escapes further analysis of

30 Supreme Court of Canada, Re Secession of Québec [1998] 2 SCR 217, 222, paras I33-I34. Also L. C. Buchheit, Secession - The Legitimacy of Self-determination (YUP, New Haven, 1978), at 220; C. Tomuschat, 'Secession and Self-Determination' in M. Kohen (ed), Secession - International Law Perspectives (CUP, Cambridge, 2006) 23, at 42.

3I Separate Opinion of Judge Antônio Augusto Cançado Trindade, para 176.

32 J. Vidmar, 'Remedial Secession in International Law: Theory and (Lack of) Practice' (2010) 6 St Antony's International Review 37-56.

33 M. Milanovic, 'Arguing the Kosovo Case' in M. Milanovic and M. Wood (eds), The Law and Politics of the Kosovo Advisory Opinion (OUP, Oxford, 2015) 2I, at 36.

34 Non-Aligned Movement, Declaration of South Summit (IO-I4 April 2000), para 54. 
technicalities required for a well-functioning State.35 It was evident in recognition of Timor Leste in 2002, which four years after raised discussion whether it had any future at all as an independent State, ${ }^{36}$ and South Sudan in 20II, which soon after its independence started to be portrayed as a 'failed State'. ${ }^{37}$ Thus, the will of people, ideally confirmed by the plebiscite or referendum, normally satisfies the international community. In the Western Sabara case, the ICJ pronounced that 'the application of the right of self-determination requires a free and genuine expression of the will of the peoples concerned' $3^{3}$ Referendum as an option for settling the Western Sahara issue was advanced for a long time by the international community and Spain as an interested party. ${ }^{39}$ The International Commission of Legal Experts addressing the question of Catalonian in its Opinion reasserted that a referendum is the best way of confirming the manifestation of popular will. It also noticed that the international legal requirements for a valid referendum are only emerging, yet it is supposed that there must be a free and fair campaign and a transparent and open balloting process as well as a predetermined threshold for the validity of an independence referendum..$^{40}$ Looking into the recent past, in the great majority of recognized consensual secessions, indeed, a form of public consultation took place. In the Soviet Union, most of the Republics held referenda. ${ }^{4 \mathrm{II}}$ In 1993, the Eritreans cast 99,8\% votes in favour of the independence from Ethiopia, in 2006 the Unionists in Montenegro were outvoted by $55,5 \%$ of those opting for independence, and in the 201 referendum in South Sudan $98,8 \%$ of the entitled people voted pro-secession. A similar, negotiated process of engendering a new State was seen in the UK, albeit with a different final result. In 20I4, a tiny majority of votes - 55,3\% determined Scotland's future within the UK.42 At the end, it worth

35 Spain, while considering recognition of South Sudan, declared: 'The independence of Sudan is legal as it is envisaged in a peace agreement promoted by the international community, apart from having been agreed by the parties, which is the most important point'. DSS-P, IX Leg., No. 106, at. 5710-5712.

36 J. Perlez, 'A Nation-Building Project Comes Apart in East Timor', NY Times (I4 July 2006), at A3.

37 A. Loewenstein, 'South Sudan is Becoming a Failed State' Aljazeera (9 Jul 2015) Opinion/Humanitarian crisis.

38 Western Sabara, supra n. 22, para 55.

39 See SC Res. 690, 29 April 1991; SC Res. 1292, 29 February 2000. For the Spanish engagement in the organization of a referendum see: DSC-C, V Leg., No. 96, at. 3079-308I; DSC-C, VII Leg., No. 393, at. I2-I3.

40 Legal Opinion by an International Commission of Legal Experts addressing the question of Catalonia: 'The Will of the People and Statehood' (27 September 2017).

${ }_{4 \mathrm{I}} \mathrm{H}$. Brady and C. Kaplan, 'Eastern Europe and the Former Soviet Union' in D. Butler and A. Ranney (eds), Referendums around the World: The Growing Use of Direct Democracy (AEI Press, Washington, 1994) 174, at 190193.

${ }^{42}$ See J. Vidmar, 'The Scottish Independence Referendum in an International Context' 5 I CYbIL (2014) 259288. 
emphasizing that non-consensual secessions will most probably remain unrecognized, regardless of the referendum results (Somaliland, Catalonia; Yugoslavia being an exception).43

The fourth and last stream illustrates the connection between recognition and democracy par excellence. A given community in this case, in order to acquire a form of a recognizable object, needs to conform to a sophisticated set of rules. Here, unlike, in the first three scenarios, the legal, moral, or stemming from a consensus right of people to govern themselves is not sufficient. Democracy in the understanding of the fourth stream either ignores or implicitly incorporates the elements of the three streams, but on top of that, demands a well-developed institutional framework. It is democracy in the fullest sense, composed both of a procedural / election-centric aspect, presupposing that people should vote (as opposed to monarchy or aristocracy) and a substantive aspect, denoting the matureness of the society, that is, its ability to implement all instruments and principles pertinent to the Western idea of democracy.44 Contemporary, such instruments and principles are: (I) the availability of the political sphere for all, regardless of wealth, race, sex, religion and class; (2) the ability to chose candidates for public offices and freedom of access to these posts; (3) the sovereignty of the nation (people) meaning that the sovereign power - inalienable and indivisible - belongs to the social community living within the borders of the State; (4) the principle of representation equivalent to the delegation of authority to representatives elected by the people in general elections and acting under its control; (5) recognition of the election as the main source of the legitimacy of power and the need to periodically confirm the legitimacy of power in the general election; (6) the possibility of associating in political parties; (7) the responsibility of the governing class - the creation of specialized institutions for the control of the authorities, intended to prevent it from abuses; (8) the separation of powers - expressing the idea of limiting government through the mutual control of the centers of power and the activities of organized political opposition; (9) freedom of belief and expression; (I0) institutional protection of civil rights - expressed in the creation of formal protection of citizens against excessive and unjustified interference of power in their affairs. ${ }^{45}$

This stream is not supported by international law whatsoever and manifests a proclivity towards one political system. The requirement of democracy par excellence, if invoked as a

43 The Spanish Constitutional Court considered the secession of Catalonia a violation of the 1978 Constitution. See judgments II4/2017, of 17 October 20I7; 259/20I5, of 2 December 20I5; and 42/2014, of 25 March 20I4. On the inapplicability of the self-determination right to the Catalans see J. Pérez de Nanclares, 'Legal Considerations Regarding a Hypothetical Unilateral Declaration of Independence by Catalonia: A Legally Unfeasible Political Scenario' is SYbIL (2015) 35, at 4I-45.

44 See generally D. Beetham, Democracy and Human Rights (Polity Press, Cambridge, 1999); T. Franck, 'The Emerging Right to Democratic Governance' 86 AJIL (1992) 46-9I.

45 D. García San José, 'El concepto de democracia en derecho internacional' i4 Revista Jurídica Universidad Autónoma de Madrid (2006) 65, at 75-87; P. Winczorek, Nauka o Państwie (Liber, Warsaw, 20II), at I23-I55. 
criterion for recognition, can be said to undermine the general principle of inclusiveness of international law. As the ICJ noted in the Western Sabara case, 'No rule of international law, in view of the Court, requires the structure of a State to follow any particular pattern, as is evident from the diversity of the forms of States found in the world today'. ${ }^{46} \mathrm{~A}$ 'forceful' implementation of democracy seems to contradict the principles of peaceful co-existence, nonintervention, and equality of States. ${ }^{47}$ According to Wheatley, although there is 'a commitment of the international community to democracy as the only legitimate form of government [...] there is $[. .$.$] no "hard" international law norm that all governments should be democratic' { }^{4}$ Moreover, this stream, if applied strictly, is in direct opposition to the principle of effectiveness widely acclaimed by international law. It comes as no surprise that this stream is also the most divisive one, whose application cannot be said to have proliferated globally.

The fourth stream is best exemplified by the democratization trend that emerged in the early I990s in the West. The dismemberment of three socialist federations (USSR, SFRY and Czechoslovakia) gave a real chance to transpose the Western political ideology into the recognition practice. ${ }^{49}$ The European Political Cooperation at an Extraordinary EPC Ministerial Meeting at Brussels on 16 December 1991 adopted 'Guidelines on the Recognition of New States in Eastern Europe and in the Soviet Union', which in its preamble explicitly expressed the readiness to (collectively) grant recognition only to those new States 'which had constituted themselves in a democratic fashion'. ${ }^{50}$ Two first principles laid down in the document squarely relate to the notion of democratic governance. These are: $(\mathrm{I})$ the respect for the provisions of the Charter of the United Nations and the commitments subscribed to in the Final Act of Helsinki and in the Charter of Paris, especially with regard to the rule of law, democracy and buman rights; (2) guarantees for the rights of ethnic and national groups and

${ }^{46}$ Western Sabara, supra n. 22, para 94. On another occasion, the ICJ dismissed the US argument that Nicaragua attempted to establish a 'totalitarian Communist dictatorship' ruling in favour of the freedom of choice of the political, social, economic and cultural system of a State. See Case Concerning the Military and Paramilitary Activities in and Against Nicaragua (Nicaragua vs United States) ICJ Reports (1986) I4, at I33, para 263.

47 Very controversial were interventions in Haiti in 1994 and in Iraq in 2003 to 'restore democracy'. See SC Res. 940, 3I July 1994, authorizing the UN peacekeeping mission in Haiti. Consult also G. Tunkin, Theory of International Law (Harvard University Press, Moscow, 1974), at 21-48.

48 S. Wheatley, The Democratic Legitimacy of International Law (Hart Publishing, Oxford, 2010), at 228. See also S. D. Murphy, 'Democratic Legitimacy and the Recognition of States and Governments' 48 ICLQ(1999) $545 \mathrm{ff}$.

49 More on the democratization trend and its application today in J. Vidmar, Democratic Statebood in International Law (Hart Publishing, Oxford, 2013), at I-I4; J. d'Aspremont, 'The Rise and Fall of Democratic Governance in International Law' in J. Crawford and S. Nouwen (eds), Select Proceedings of the European Society of International Law (Hart Publishing, Portland, 20I2), at 6I.

so European Political Cooperation, 'Guidelines on the Recognition of New States in Eastern Europe and in the Soviet Union', adopted at an Extraordinary EPC Ministerial Meeting at Brussels (I6 December 199I), reprinted in $3 \mathrm{I}$ ILM I486, para 3. 
minorities in accordance with the commitments subscribed to in the framework of the CSCE. The Charter of Paris (officially the Charter of Paris for New Europe) as lex specialis to the 'Guidelines' constitutes a distinctive bedrock of the democratization policy. ${ }^{51}$ It embraces clauses postulating that 'Europe is liberating itself from the legacy of the past [...].' 'Democratic government is based on the will of the people, expressed regularly through free and fair elections [...]'. 'Democracy has its foundation respect for the human person and the rule of law [...]'. 'Democracy is the best safeguard of freedom of expression of all groups of society, and equality of opportunity for each person', etc. .2 $^{2}$ The 'Guidelines', at first sight, resembling a political manifesto, and by its very nature reflecting 'soft law', had though considerable ramifications in practice. For instance, procrastination in receiving assurances from Kyrgyzstan, Tajikistan, and Georgia on their readiness to conform with requirements enunciated in the 'Guidelines' postponed their recognition by the EC Member States until 16 January 1992 (Kyrgyzstan and Tajikistan) and 23 March 1992 (Georgia). Of commensurable content and application with the 'Guidelines' was the EC Declaration on Yugoslavia which mirrored the common position of the European Community with regard to the recognition of Yugoslav Republics. 53 The Community agreed to recognize the independence of all the Yugoslav Republics subject to the acceptance of the commitments contained in the 'Guidelines'. ${ }^{54}$ The Badinter Commission, which was called to adjudge the 'readiness' of the Republics, reached different conclusions and issued different recommendations regarding the recognition. It noted that Slovenia and Macedonia satisfied the prerequisites embedded in the 'Guidelines' (Opinions No. 6 and 7 , issued on II January 1992),5 remarked that Croatia, subject to a reservation (minority protection standards), meets the necessary conditions for its recognition by the Member States of the European Community (Opinion No. 5 of II January 1992).56 The Commission commented on the internal settings of the B\&H (Opinion No. 4 of II January 1992) and the FRY (Opinion No. Io of 4 July 1992), however, did not explicitly recommend recognition. ${ }^{77}$ It is worthy of note that several other States, not at the time members of the European Community, referred to the fulfilment of similar criteria (the case of Switzerland and Austria)..$^{8}$ In his speech in 199I,

\footnotetext{
SI Conference on Security and Co-operation in Europe, Charter of Paris for a New Europe (2I November I990), reprinted in (1991) 30 ILM 193.

52 Cf. UDHR, Art. 2I and ICCPR, Art. 25 (no reference to multiparty setting is made).

53 EC Declaration on Yugoslavia (16 December 199I), reprinted in (1992) 3I ILM I485-I486.

$54 \mathrm{Ibid}, \mathrm{I} 485$.

55 Badinter Arbitration Commission, European Community Conference on Yugoslavia, Opinions No. 6 and 7 (II January 1992), reprinted in D. Turk, 'Recognition of States: A Comment' 4 EJIL (1993) 66, at 77-84.

56 Ibid, at $76-77$.

57 Ibid, at 74-76 (BIH) and 90-9I (FRY).

58 J. Frowein, 'The Contribution of the European Union to Public International Law' in Armin von Bogdandy (ed), European Integration and International Coordination (Kluwer, The Hague, 2002) I71, at 174.
} 
the US Secretary of State, James Baker, conditioned recognition on 'five internationally accepted principles': (a) determination of the future in peaceful and democratic processes; (b) respect for all existing borders; (c) support for democracy and the rule of law; (d) safeguarding of human rights, based on full respect for the individual and including equal treatment of minorities; (e) respect for international law and obligations.99

The exaggerated adherence to the recommendations on recognition issued by the Badinter Commission in view of the fulfilment of democratic principles by the Yugoslav Republics was subsequently vociferously criticized. Most notably, they were in conflict with the ordinary methods of statehood assessment (Montevideo criteria). Croatia and Bosnia were recommended for recognition and received it, while not being able to exert effective control over the great part of claimed territories. The FRY, on the other hand, met all the Montevideo criteria, yet was not issued such an advice and remained unrecognized until 1996.60

Contemporarily, States continue to refer to the notion of democracy par excellence as a requirement for statehood. For example, in Slovenia's opinion, Kosovo has undertaken to respect the 'commitments under the Comprehensive Proposal for the Kosovo Status Settlement, particularly regarding respect for ethnic groups, the protection of cultural and religious heritage, and the international supervision of Kosovo' ${ }^{6 r}$ Slovenia in her statement explicitly cites the 'Guidelines' provisions. ${ }^{62}$ Denmark too praises highly the readiness and capability of an entity to govern itself effectively and democratically. Denmark stressed that she has so far contributed more than EUR 20om to stabilize Kosovo and help to develop a multi-ethnic, democratic society. Furthermore, 'in its declaration of independence, Kosovo undertook to protect and promote the rights of all communities in a democratic, saccular and multiethnic republic. In expressing their recognition, Denmark and other States placed significant emphasis on these obligations' ${ }^{6}{ }^{63}$ The US acknowledged that to the main factors that undergirded the United States' decision on the recognition of Kosovo's independence on 18 February 2008, belong the question of 'democratic fitness'. ${ }^{64}$ The United States placed great weight on Kosovo's commitments, assumed in its declaration of independence and subsequently in its constitution, to protect the rights and interests of all communities in

59 Reuters, 'Soviet Turmoil'; Baker's Remarks: Policy on Soviets, N.Y. TIMES (5 September 199I), at Ar2 (reprinting speech given by Secretary of State James Baker on September 4, 199I).

60 The unrecognition of the FRY was highly political and predicated on its claim to be a continuator of the SFRY. M. Craven, 'The European Community Arbitration Commission on Yugoslavia' 66 BYbIL (1996) 333, at 370-375. Also B. Roth 'Ne-konsensualna disolucija država u međunarodnom pravu: Inovacija Badinterove komisije u retrospektivi' 52 Politička Misao (2015) 48, at 56-57, 62.

6r Written statement of Slovenia (I7 April 2009), at 2-3.

62 Ibid, at 3 .

63 Written statement of Denmark (I7 April 2009), at I, II-I2.

${ }^{64}$ Written statement of the US (17 April 2009), at 35. 
Kosovo. In the letter to President Sejdiu, the US President George W. Bush stated that in recognizing Kosovo as an independent and sovereign state, the United States 'support your embrace of multi-ethnicity as a principle of good governance and your commitment to developing accountable institutions in which all citizens are equal under the law'.65

\section{(C) THE PROBLEMATIC RELATIONSHIP BETWEEN FOUR DEMOCRACY STREAMS}

It is universally acknowledged that every organized community should be allowed to govern itself, which nota bene does not necessarily denote an independent statehood. The practice of recognition of States confirms the full realization of the will of people in the form of statehood in the first stream (unequivocal legal right of colonized people, which may be protracted) and in the third stream (consensual secession). The recognition of the endogenous will of people to create a State is generally withheld in the second stream (moral recognition, with few exceptions, like Kosovo) and in the great part of the first stream (legal) due to the principle of territorial integrity, prohibition of the use of force, and excessive regard paid to internal selfdetermination. Nevertheless, it stands to reason that streams may interfere with each other. For example, the second (moral) stream could be invoked within the ambit of the first one (legal) but also of the third one (consensual). The recognition of an entity as a State is in and of itself cloaked by morality. The fourth stream, owing to its intrusive character, may or may not be in harmony with the remaining streams. The imposition of a specific political regime, entailing procedural aspect (voting) and substantive aspect (liberal and economic principles) may cast doubts on the morality of recognition as well as contrast with the idea of self-determination itself. Different opinions are espoused in that regard. For Franck, self-determination is a building block of democratic entitlement. ${ }^{66}$ Etzioni, however, is not optimistic about the capacity of self-determination to advance democracy. He argues that 'with rare exceptions', self-determination movements actually 'undermine the potential for democratic development in non-democratic countries and threaten the foundations of democracy in democratic ones' ${ }^{67}$ In the same vein, Miller observed that behind this guise of democracy often hides 'ethnicnationalism, which has led to the creation of numerous undemocratic states'. ${ }^{68}$ Vidmar propounded that the political obligation of multiparty electoral democracy does not lead to an

\footnotetext{
${ }_{65}$ Letter from United States President George W Bush to President of Kosovo Fatmir Sejdiu (I8 February 2008). Weekly Compilation of Presidential Documents, Volume 44, No. 7 (25 February 2008), at 236.

66 Franck, supra n. 44, at 52.

67 A. Etzioni, 'The Evils of Self-Determination' 89 Foreign Policy (1992-1993), at 2 I.

68 R. Miller, 'Self-Determination in International Law and the Demise of Democracy?' 4I Columbia Journal of Transnational Law (2003) 60I, at 6IO.
} 
automatic realization of the right of self-determination. ${ }^{69}$ Finally, some authors claim that there is no conclusive nexus between democracy and general well-being and higher living standard. $7^{\circ}$ For Peterson, statements redolent of the UN Secretary-General, contained in his Agenda for Peace (1992), that 'there is an obvious connection between democratic practices - such as the rule of law and transparency in decision making - and the achievement of true peace and security in any new and stable political leadership's are examples of the teleological dogmatism leading to the proliferation of one system, often connected with the installation of a legitimate' governor $7^{2}$ Thus, the recognition of a claim to statehood exercised through the external selfdetermination (first three streams) is not always synonymous with democracy par excellence (fourth stream) and vice-versa.

\section{(D) FOUR DEMOCRACY STREAMS IN THE CONTEMPORARY RECOGNITION PRACTICE OF THE EUROPEAN UNION AND ITS MEMBER STATES}

This part seeks to determine to which stream(s) of democracy adheres the European Union while arriving at the decision to recognize a new State. Of particular interest will be whether the demand of democracy par excellence (fourth stream), for which it was renowned in the I990s, retains validity today. To do so, the stance of the EU as a whole, as well as its Member States, and its institutions will be analysed in the context of (non)recognition of four most recent statehood claims: Palestine, Montenegro, Kosovo and South Sudan.

Palestine proclaimed independence on I5 November 1988, which until now is recognized by I36 out of 193 Member States of the United Nations (70\%) and 9 out of 28 Members of the European Union (32\%). For that reason, it is not possible to talk of coordinated, group recognition and the problem has to be dealt with from the perspective of particular Member States' decisions and activities of the EU institutions. In fact, only Sweden recognized Palestinian statehood as a Member of the EU; all other States did it prior to accession (Poland, Hungary, Romania). It seems that Sweden, as well as the majority of Eastern European States,

${ }^{6}$ J. Vidmar, 'The Right of Self-Determination and Multiparty Democracy: Two Sides of the Same Coin?' Io Human Rights Law Review (2010) 239-268.

70 A. Leftwich, States of Development: On the Primacy of Politics in Development (Polity, Cambridge, 2000), at 129 .

${ }_{7 \pi}$ UNGS, An Agenda for Peace: Preventive Diplomacy, Peacemaking and Peace-keeping, I7 July 1992, UN Doc. A/47/277 S/24III, para 59. See also Vienna Declaration and Programme of Action, 29 June 1993, UN Doc. A/CONF.157/23, para 8; 'Progress Review and Recommendations' adopted by the Third International Conference of the New or Restored Democracies on Democracy and Development held at Bucharest from 2 to 4 September 1997, UN Doc. A/52/334, Appendix.

${ }_{72}$ N. Petersen, Demokratie als Teleologisches Prinzip: Zur Legitimität von Staatsgewalt im Völkerrecht (Springer, Berlin, 2009), at 59-139. 
recognized Palestine within the first (legal) and second (moral) stream. As indicated before, Palestine, as a relic of colonization, enjoys the unequivocal right to self-determination, which includes the right to statehood.73 The realization of the said right may, however, prolong and depend on an agreement in contentious cases. Margot Wallström, Swedish foreign minister, while explaining Swedish recognition stated that 'It is an important step that confirms the Palestinians' right to self-determination. [...] We hope that this will show the way for others' 74 Sweden might have relied also on a moral stream, which in the cases of a protracted inability to overcome an impasse and human rights violations could justify recognition. According to the official statement, Sweden has seen the escalation of Israeli Settlements, violence in Jerusalem and on the West Bank, and on top of that, three wars in Gaza'.75 In all likelihood, it will the first and the second stream that will constitute the benchmark for future recognition of Palestinian statehood. Josep Borrell, Spanish Minister of Foreign Affairs, European Union and Cooperation announced on 20 September 2018 that recognition of Palestine is on the government's' table, since the stalemate, which is conducive to human rights violations of the Palestinians, cannot be tolerated indefinitely. ${ }^{76}$ For obvious reasons, the third stream (consensual) which could underpin the decision on recognition has to be excluded. The fourth stream demanding democracy par excellence seems also not to have been of much relevance in the case of Palestine. The state-building process lasts, and the EU involvement in the democratization and human right protection continues. 77 The review of policies implemented by the European Instrument for Democracy and Human Rights (EIDHR) in Palestine during 2011 and 2015 suggests that democracy is far from stable, notwithstanding the possible differences between the notions of this term around the world. It observed that the most significant violations of human rights and democratic principles included infringements of International Humanitarian Law (IHL) and the United Nations (UN) Conventions on human rights, especially on the prohibition of torture, arbitrary detention, legal defence, freedom of movement and residence, freedom of expression, assembly and association and fundamental economic rights, such as the right to water and the right to work (mostly referring to territories under Israeli control) $7^{7}$ The Annual Report on Human Rights and Democracy in the World

73 GA Res. I54I, supra n. 22. See also United Nations Partition Plan for Palestine: GA Res. I8I(II), 29 November 1947 .

74 Available here, accessed ro October 2018.

75 Video available here, accessed ro October 2018.

76 Available here, accessed ro October 2018.

77 See G. Denoeux and R. Springborg, Promoting Democracy and State Building in Palestine (Saffron Books, London, 2005); D. Bouris, 'The European Union's Role in the Palestinian Territory after the Oslo Accords: Stillborn State-building' 6 Journal of Contemporary European Research (2010) 376-394.

${ }^{8}$ ODIHR, 'Review of the Effectiveness of the EIDHR Programme in Palestine 20II - 2015', accessed Io October 2018. 
2016 clearly distinguished between responsibilities of the Palestinian Authority and Israeli authorities in the occupied territories. It concluded in reference to the former that '[...] Respect for freedom of expression, freedom of assembly and freedom of the media did not improve; they came under increased pressure due to harassment, threats and sometimes arbitrary arrests of journalists. 2I death sentences were handed down in Gaza, but none in the West Bank thanks to a moratorium. [...] In general, fundamental freedoms and human rights are anchored in the Palestinian Basic Law, but effective implementation is often not guaranteed. [...] There are various problems especially in the fields of gender, (domestic) violence against women and discrimination against LGBTI persons. Persons with disabilities continue to suffer from social exclusion. Arbitrary detention has remained a matter of concern. There were regular reports of torture and ill-treatment in detention centres. Freedom of expression in Gaza is still under severe pressure with attacks on journalists [...].' 79

That being said, Sweden did not follow the fourth stream. The situation of other EU States, which do not recognize Palestine, is less clear but it appears that the major obstacle in that regard is not the compliance with the set of democratic principles but the fact that Palestine does not meet standard statehood criteria, as underlined by the UK during the voting on Palestine's status in the UN in 2012, ${ }^{80}$ which diverges by and large from the position previously taken in Yugoslavia.

The EU institutional outlook appears to back Palestinian statehood. Javier Solana, the EU 'foreign policy' chief, at the end of his tenure in 2009 called for the United Nations to recognise the Palestinian State by a set deadline, even though a settlement had not been reached. Similar approach was taken by his successor Catharine Ashton who called for a 'two-State solution'. ${ }^{\text {. }}$ The Council of the European Union (Foreign Affairs) at its meeting on I3 December 2010 confirmed readiness, when appropriate, to recognize a Palestinian State. It reiterated the 'twoState solution' by stating 'We want to see the State of Israel and a sovereign, independent, democratic, contiguous and viable State of Palestine living side by side in peace and security. ${ }^{82}$ In the statement, we also read 'the right of Palestinians to achieve statehood must never be called into question' ${ }^{{ }_{3}}$ Furthermore, the EU commended building of the institutions of the future State of Palestine, praised Fayyad plan (reform and development plan, based on neoliberal agenda), and welcomed the World Bank's assessment that if the Palestinian

\footnotetext{
79 Annual Report on Human Rights and Democracy in the World 2016, at 67-69, accessed ro October 2018.

80 UN Doc. A/67/PV.44, at 15.

${ }_{8}$ M. Alagha, Palestine in EU and Russian Foreign Policy: Statehood and the Peace Process (Routledge, Oxford, 2017), at 4 .

82 Council of the European Union, Press release No. $17835 /$ io of the 3058 th Council meeting on Foreign Affairs, at 2.

$83 \mathrm{Ibid}$, at $\mathrm{I} 3$.
} 
Authority maintains its current performance in institution building and delivery of public services, it is well positioned for the establishment of a State at any point in the near future'. ${ }^{{ }_{4}}$ At the same time, it underscored governance deficiencies in Gaza. Finally, the EU Council affirmed its 'readiness to contribute to a negotiated solution on all final status'. Various pronouncements of the EU Council do not admit of an easy answer as to which stream is preponderant. Although it mentions legal, as well as democracy par excellence streams, due to the provisions 'when appropriate' and 'readiness to negotiated solution', it is plausible to contend that the third stream (consensual) will prevail in the case of the recognition of Palestine by the Council. In contrast, the EU Parliament in its resolution on recognition of Palestine statehood of 17 December 2014 gave preference to the first (legal) and second (moral) stream, emphasizing the due regard to international law and the fact that direct peace talks between the parties are stalled. With that in mind, it opted for the recognition of Palestinian statehood as the most viable solution. The peace talks and state-building should continue notwithstanding. ${ }^{85}$ Nevertheless, it should be borne in mind that so long as the individual (Western) States do not make their minds to definitely recognize Palestine as a State, everything else will remain an institutional rhetoric, which may continue for a long time.

The second example of invoking democracy in the EU recognition policy framework is evident in its recognition of Montenegro. Montenegro proclaimed independence on 3 June 2006, after a slim majority of people chose in an agreed referendum to separate from the State Union of Serbia and Montenegro. The EU respected the referendum results and welcomed the new State, with which it wishes to cooperate and which has the prospect of joining the European Union. ${ }^{86}$ The focal point of affording recognition in the case of Montenegro was the third stream i.e. consensus, which, as mentioned before, requires that the will of people is substantiated, ideally in a referendum carried out by appropriate standards. To this end, the only conditions imposed were the $55 \%$ supermajority of votes in favour and a minimum turnout of $50 \%$ as proposed by the EU special envoy Miroslav Lajč́k and endorsed by the EU Council. ${ }^{87}$ Given that both requirements were met, the Presidency on behalf of the European Union declared that it welcomes the 'successful organisation of the referendum on the independence' which was in line with OSCE and Council of Europe standards for democratic electoral processes. Moreover, 'the conduct of the referendum was a sign of maturity of the political forces and people of Montenegro'. In light of that, it called on all sides concerned to

\footnotetext{
84 Ibid, at I4.

${ }^{85}$ European Parliament, Resolution (2014/2964(RSP)) (I7 December 2014) on recognition of Palestine statehood.

86 'Statement by the EU Commissioner for Enlargement Olli Rhen', accessed ro October 2018.

${ }^{87}$ See in Parliamentary Assembly of the Council of Europe, 'Documents: working papers' 2006 ordinary session (third part) (26-30 June 2006) Documents I095I-I0996, at 216-218.
} 
accept the result. ${ }^{88}$ The first (legal) and second (moral) streams were absent, as Montenegro was neither colonized or occupied after 1945 nor had it a track of harrow struggle for independence. The fourth stream was either assumed as the State Union of Serbia and Montenegro was a recognized State before, or was subordinated to the third consensual stream. The latter assumption might be validated by taking into consideration the $2016 \mathrm{EU}$ Commission report on Montenegro's accession negotiation achievements. The Commission noted that Montenegro is 'moderately prepared' in areas of public administration, the judicial system and fight against corruption. More progress is needed in the province of the fight against organized crime. The implementation of legislative reforms to align with the EU standards on human rights remains weak. There exist room for improvement in the area of freedom of expression. ${ }^{89}$ Taking a closer look at the situation of Montenegro, it might be also that what was then a requirement for statehood (Guidelines) is now a requirement for admission.

Kosovo declared independence on 17 February 2008, which as of now has been recognized by III UN Member States (57\%) and by 23 out of 28 EU Member States (82\%).90 Owing to the division on the status of Kosovo between the EU Members States, a collective recognition reminiscent of that of Montenegro two years earlier, could not be achieved. Kosovo has been recognized by the EU Member States mainly within the ambit of the second stream (moral). Needless to say that the first and third are not applicable - Kosovo is not a vestige of colonialism and a consensus between it and Serbia has not been reached.9 ${ }^{9}$ The fourth stream providing for a well-functioning democratic society has played an important role, albeit rather as a consequence of recognition or something which is on a right path to be achieved. In other words, the recognition of Kosovo is said to enhance stability and democracy and there is a viable prospect that the existing institutional framework will lead to a well-functioning democratic State. This is evident in written submissions of the EU States that have recognized Kosovo. Finland expounded the moral element of recognition (second stream) by stating that 'The decision by Serbia to curtail the internal self-determination of Kosovo in the late I980s was closely connected with the policy that led to the violent break-up of the federation'. She

88 Declaration of 23 May 2006 by the Presidency on behalf of the European Union regarding the referendum in Montenegro ( $\mathrm{P} / 06 / 73)$.

89 European Commission, Commission Staff Working Document 'Montenegro 2016 Report' (9 September 2016) $\operatorname{SWD}(2016) 360$ final, at 6-21, 53-73.

90 Kosovo is said to have lost recognition of six countries since November 2017. Suriname, Burundi, Guinea Bissau, Liberia, São Tomé and Príncipe and Papua New Guinea have purportedly revoked their recognitions, accessed Io October 2018.

91 See 'First Agreement of Principles Governing the Normalization of Relations' (Brussels Agreement) (I6 April 20I3), accessed Io October 20I8. Spain, justifying its non-recognition of Kosovo, explained that there are only two means to accept the secession of a State - through the approval of the UN Security Council or through the approval of the parties. I6 SYbIL (20I2) 95, at I05. 
went on to claim that 'The Milosevic regime continued to pursue a deliberate policy of repression and persecution with regard to Kosovo, seeking to ensure that the ethnic Albanian majority in Kosovo become politically powerless.' ${ }^{22}$ Finally, Finland referred to Milutinovic et al. case, which points to excessive and indiscriminate force used by the forces of the FRY and Serbia in 1998 against the Kosovo Albanian civilian population. ${ }^{93}$ As per the fourth stream, Finland conceded that States created out of a violent struggle rarely fulfil ideally criteria of democratic representation. However, she added that the declaration of independence was based on the Constitutional Framework and that only international recognition of Kosovo could secure lasting solution for peace and respect for fundamental rights and freedoms. ${ }^{94} \mathrm{~A}$ similar dichotomy of invoking both streams is present in the majority of other statements. Poland justified recognition in virtue of the second stream, contending that Kosovo is a sui generis case. In Poland's opinion, Serbia did not provide sufficient guarantees to the protection of fundamental human rights and violated these rights by depriving Kosovo of autonomy. As a consequence, Serbian territorial integrity eroded.95 Besides, Poland alluded to the United Nations Mission in Kosovo (UNMIK) which assumed all legislative, executive and judicial authority throughout Kosovo and the 'Comprehensive Proposal for the Kosovo Status Settlement' which in the first paragraph provides that 'Kosovo shall be a multi-ethnic society, which shall govern itself democratically, and with full respect for the rule of law, through its legislative, executive, and judicial institutions. ${ }^{96}$ It follows that a blind eye is turned to current deficiencies of democracy, which could be rectified with time and the overall situation of democracy improved within the international institutional framework in Kosovo. ${ }^{97}$ The international institutional framework was installed in Kosovo pursuant to UN Resolution I244, which decided on the deployment of a civil mission in Kosovo (UNMIK).98 UNMIK's mandate envisages, inter alia, the performance of civilian administrative functions, promotion of selfgovernance in Kosovo and protection and promotion of human rights.99 On I5 May 200I, UNMIK enacted the 'Constitutional Framework for Provisional Self-Government', a set of rules resembling a constitution, which established organs of self-government (chapter I),

92 Written statement of Finland (I6 April 2009), at 5.

93 ICTY, Prosecutor v. Milutinovic et al (Judgement of 26 February 2009) Case No. IT-05-87-T, at 324-325, 350.

94 Written statement of Finland (16 April 2009), at 9-IO.

95 Written statement of Poland (I8 April 2009), at 2I-23, 27-29.

96 Ibid, at 16-I7.

97 Serious concerns about democratic governance were expressed in the EU Parliament Resolution $2008 / 2663$ (RSP). For current concerns refer to European Commission, Commission Staff Working Document 'Kosovo 2016 Report' (9 September 2016) SWD(2016) 363 final, at 6-30, 65-72.

98 SC Res. 1244, I0 June 1999.

99 Available here, accessed ro October 2018. 
affirmed commitments to most international human rights instruments (chapter 3), stipulated law and order (chapter 6) and set out powers and responsibilities reserved to the SRSG (chapter 8). ${ }^{100}$ On 4 February 2008, the Council of the European Union established the European Union Rule of Law Mission in Kosovo, which assists Kosovo's judicial authorities and law enforcement agencies in their progress towards sustainability and accountability. ${ }^{\text {Ior }}$

Given the great majority of the EU States recognize Kosovo, some analogies are expected in the works of the EU institutions as well. In opposition to the deadlock in the EU Council, which determined that each State should decide alone on its relations with Kosovo, ${ }^{\text {Io }}$ the EU Parliament strongly urges States to recognize Kosovo. In its recent resolution on the 2015 Report on Kosovo, it underlined that five EU States that currently do not recognize Kosovo should follow suit, as this would help to strengthen stability in the region. ${ }^{103}$ At the same time, the position of the EU Parliament can hardly be squared with any of the four streams. It does not refer to any legal or moral foundations for statehood, what is more, it does not make statehood conditional upon the bilateral agreement. Lastly, in its first resolution after the unilateral proclamation of independence by Kosovo of 5 February 2009, the Parliament called for the recognition of Kosovo, yet in the same text emphasized serious concerns about democratic governance, which in turn means that it has not held on to the fourth stream either. ${ }^{104}$

South Sudan is the newest country and the last example referred to in the present analysis, where the EU and its Member States alluded to the idea of democracy while justifying recognition. South Sudan declared independence on 9 July 2oIr, which on the same day was positively received by the European Union. Two days later, South Sudan got admitted to the United Nations. In the case of South Sudan, the third stream (consensual) was of the utmost importance. ${ }^{\text {Ios }}$ The first should be excluded, as it was a part of Sudan before, not any other colonizer. Likewise, the fourth stream should be renounced - South Sudan is virtually a failed State. The second stream, though, could have left some impact in view of the half-century-long conflict between the north and south part. Notwithstanding, at the core of the EU and its Member States' recognition decision lies the long-negotiated 2005 Comprehensive Peace

${ }_{100}$ UNMIK Regulation No. 200I/9 (I5 May 200I) UNMIK/REG/200I/9.

ror Council of the European Union, Council Joint Action 2008/124/CFSP.

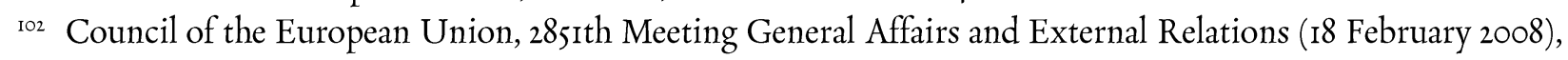
Conclusions on Kosovo, Doc. 6262/o8.

${ }^{103}$ European Parliament, Resolution on the 2015 Report on Kosovo (4 February 2016), Doc 2015/2893(RSP).

${ }^{104}$ European Parliament, Resolution on Kosovo and the role of the EU (5 February 2009), Doc $2008 / 2663$ (RSP).

ros S. Sheeran, 'International Law, Peace Agreements and Self-Determination: The Case of Sudan' 60 ICLQ (201I) 423 , at $443-445$. 
Agreement culminating in a referendum. ${ }^{106}$ According to the official EU declaration, the 'referendum was conducted peacefully and credibly and its outcome was a true reflection of the democratically expressed wishes of the people of South Sudan'. ${ }^{107}$ In the same text, the EU expressed hope that South Sudan's leaders will embrace diversity and pluralism and lay the foundation for a democratic, inclusive and fair society, based on the rule of law and respect for human rights and fundamental freedoms. ${ }^{\mathrm{I} 8}$ This means that democracy is yet to be established appropriately and did not play a critical role in the EU recognition of South Sudan. ${ }^{\text {109 }}$ In that respect, South Sudan, mindful of a political, social and economic distinctiveness, resembles Kosovo, where democracy par excellence is to be attained at some point in the future, a basis for which is the internationally arranged framework. In South Sudan's case, democratization should be realized with the assistance the United Nations Mission in South Sudan (UNMISS), the European Instrument for Democracy and Human Rights and pursuant to the 2015 Agreement on the Resolution of the Conflict in South Sudan. ${ }^{\text {II }}$

\section{(E) CONCLUSION}

The analysis of the recent EU policy on recognition shows that the infamous 'Guidelines' have lost validity. The requirement of democracy par excellence is undoubtedly superseded by a democratic consensus between the Mother State and the seceding entity as evidenced by the examples of Montenegro and South Sudan. Both entities, upon the successful outcomes of referendums, were uniformly accepted by the EU Member States and the EU institutions as sovereign States, despite (serious in the case of South Sudan) room for improvement of democratic governance standards. In the case of a divided opinion on a statehood claim among the EU Members, again, it is rather not democracy in its fullest sense that substantiates the decision on recognition but an aspect of a legal or moral right to self-determination. Palestine was recognized by Sweden on account of its legally affirmed right to statehood and humanitarian law considerations. Kosovo was primarily recognized on a moral basis. Regard to democracy is paid, albeit in the future context. The EU Member States, as well as the

${ }^{106}$ Declaration by the EU and its Member States on the Republic of South Sudan's independence (9 July 20II), Doc 2679/I/II REV I.

I07 Ibid, at I.

${ }^{108} \mathrm{Ibid}$, at 2.

rog The UN, while establishing mission in South Sudan (UNMISS), specified that one of its main goals should be strengthening of the capacity of the Government of the Republic of South Sudan to govern effectively and democratically. SC Res. 1996 (20II), 8 July 20II. For evidence that South Sudan is far from achieving good governance see Report of the Commission on Human Rights in South Sudan (6 March 2017) A/HRC/34/63, at 7-16.

Iо SC Res. 2290, 3I May 2016. 
European Parliament, believe that a solid democracy can be established subsequently within the international institutional framework and recognition can only assist peace and democracy. There are three possibilities to address the issue of why the then stringent adherence by the EC to 'good governance' and human rights has given the floor to the rudimental understanding of democracy based on the legal, moral or consensual right to self-determination. Firstly, the EU prefers to introduce the requirement indirectly, which is a less controversial method in terms of international law in the eyes of the public. Democratization can be achieved in futuro by a less coercive means, for example, within the international legal framework. Secondly, there is no real prospect of the emergence of new States in the vicinity and interests of the European Union. The EU does not want to stand out in the international arena. Lastly, it is possible that the criterion of headful attendance to good governance, democracy and human rights has only changed levels and terminology. The EU will recognize a candidate as a 'Member State' only upon the fulfilment of substantially the same, if not stricter, criteria for admission. ${ }^{\text {III }}$

III 'Any European State which respects the values referred to in Article 2 and is committed to promoting them may apply to become a member of the Union'. Article 2 spells out that 'The Union is founded on the values of respect for human dignity, freedom, democracy [...]'. Consolidated Version of the Treaty on European Union [2008] OJ Cirs/13, Art. 2. 